\title{
The Value Relevance and Subjectivity of Other Comprehensive Income
}

\author{
Meichyel Meichyel*, Novy Silvia Dewi \\ Sekolah Tinggi Manajemen PPM \\ Jakarta, Indonesia \\ *mariameichyel@gmail.com
}

\begin{abstract}
This study aims to determine the effect of net income, comprehensive income, other comprehensive income, other comprehensive income with low subjectivity, and other comprehensive income with high subjectivity on stock returns. This research was conducted on infrastructure, utilities, and transportation companies listed on the Indonesia Stock Exchange (IDX) for the period 2014-2018 using panel data regression analysis with Eviews 9. The results of this study indicate net income variable affects stock returns positively, comprehensive income, other comprehensive income, and other comprehensive income with high subjectivity affect stock returns negatively, and other comprehensive income with low subjectivity does not affect stock returns.
\end{abstract}

Keywords-value relevance, subjectivity of other comprehensive income, stock return

\section{INTRODUCTION}

Financial Accounting Standards in Indonesia are adopted from International Financial Reports Standards (IFRS). Financial Accounting Standards (SAK) contain Statement of Financial Accounting Standards, called PSAK. PSAK specifically regulates the presentation of financial statements in PSAK 1 about Presentation of Financial Statements. PSAK 1: Presentation of Financial Statements contains statements that regulates the presentation of financial statements, the structure of financial statements, and the minimum requirements for the contents of financial statements.

Information in financial statements is useful for investors to make investment decisions. Investors will consider the rate of return of shares to be received. Stock returns are a reward for investors for risks taken in their investment activities [1]. For this investment, investors will benefit from an increase in share prices or losses due to a decline in the value of the stock price. An increase or decrease in stock prices will affect stock returns. In 2015 - 2018, specifically in Indonesia, there were fluctuations in share prices in infrastructure, utilities, and transportation companies. In 2015, this sector index closed on 30 December 2015 with 981,333 points. In 2016, this sector index closed on 30 December 2016 with 1,055,587 points. Then in 2017, the sector index closed on December 29, 2017, with $1,183,708$ points. While in 2018 , there was a decline to reach $1,064.29$ points (Figure 1).

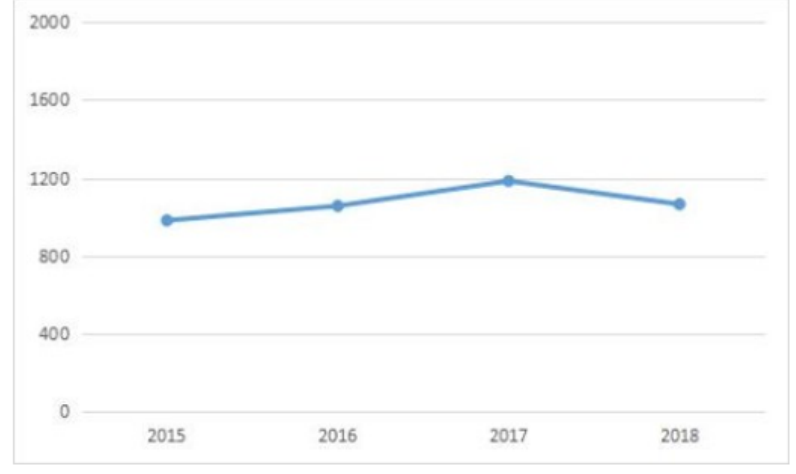

Fig. 1. Closing price of the infrastructure, utility, and transportation sector index.

According to Anthonius Edyson, Head of Research at Astronacci International, for the long term, the outlook for infrastructure issuers is still considered quite positive (www.investasi.kontan.co.id). Although there are changes that cause an increase or decrease in share prices for the infrastructure, utilities, and transportation sectors, the stock index of this sector is estimated to be quite positive. This is because aspects of infrastructure development are still the focus of the government. Changes in stock prices that occur continuously can affect the returns to be received by investors. Investors rely on information in financial statements before making investment decisions.

In 2013, the Financial Accounting Standards Board (DSAK) in Indonesia revised the Statement of Financial Accounting Standards (PSAK) 1 regarding the presentation of financial statements which added the components of other comprehensive income (OCI) to the statement of profit or loss and other comprehensive income. The component of OCI consists of unrealized gains or losses that provide more comprehensive information to users such as investors for investment decisions. In measuring and evaluating component of OCI, subjectivity is contained due to estimations, assumptions, and judgments [2]. Several studies have been carried out and there are gaps in research results. Based on research conducted by Groen, net income affects stock return positively [3]. Research conducted by Rejeki and Warastuti concluded that changes in net income does not affects stock return positively, comprehensive income affects stock return positively [4]. Based on research conducted by Yudiman et al the results show that net income per share has no significant effect and negative on stock return, comprehensive income has no significant effect and positive on stock return, and other 
comprehensive income has significant effect and positive on stock return [5]. According to research conducted by Kahareningtyas, it was concluded that the effect of other comprehensive income on stock returns cannot be statistically proven [6]. Research conducted by Aryati and Wibowo concluded that other comprehensive income affects stock return negatively [7]. Based on the differences or gaps that occur in previous studies that have been described above, researchers want to conduct similar study related to the value relevance of the statement of profit or loss and other comprehensive income. the statement of profit or loss and other comprehensive income have information that can give signals to investors who want to consider their investment activities to get the maximum return.

\section{LITERATURE REVIEW AND HYPOTHESIS DEVELOPMENT}

\section{A. Signaling Theory}

Company managers provide information through accounts that signal investors to help make investment decisions [8]. Signal theory in the context of management explains that financial statements are basically used by companies to convey both positive and negative signals to users of financial statements [9].

\section{B. Value Relevance}

In the Financial Accounting Standard Board (FASB) the purpose of financial reporting is to provide useful information to investors, creditors, and other users for investment decision making, credit, and other economic decision making [10]. Value relevance is measured by the ability of information in financial statements to convey information that affects stock prices [11].

\section{Net Income}

Net profit or loss is the difference between income and profits and expenses and losses [12,13]. Investors rely on the value of operational items (all components related to the company's operational activities) that are in net profit [14]. Net income will provide information that can imply a signal for investors in making investment decisions. Signals sent by management through the publication of financial statements will be responded to by investors. Investor response will influence investment decisions and will affect stock returns.

According to Obinata, information in net income is useful for investors in making investment decisions where this is in line with the main objective of accounting standard policies, which is to have useful information for its users [15]. According to Darsono, net income has value relevance so information in net income is useful and can be used as a basis for users of financial statements in making decisions [16]. According to research conducted by Ariyadi et al shows the results that net income per share has an effect on stock returns [17]. According to research conducted by Aryati and Wibowo, the results show that net income has an influence on stock returns [7]. The first hypothesis is derived as follows:

\section{$\mathrm{H}_{1}$ : Net income affects stock return.}

\section{Comprehensive Income}

According to Hery, comprehensive income consists of unrealized gains and losses that are not reported in the income statement [12,13]. According to Brimble and Hodgson, proponents of understanding comprehensive income argue that with comprehensive income, it is possible to include items that add value relevance [18]. Therefore, comprehensive income provides more information and makes reports more relevant. When the information presented has relevance, the level of investor confidence increases and then stimulates investors to invest so that it will increase stock returns. According to the research of Rejeki and Warastuti, the results show that comprehensive income affects stock returns [4]. According to the research of Usman et al comprehensive income has an effect on stock returns which indicates that the stock market reacts to the value of comprehensive income [19]. Then, according to Ariyadi et al comprehensive income has an effect on stock returns [17]. Then derived the second hypothesis, as follows:

\section{$\mathrm{H}_{2}$ : Comprehensive income affects stock return.}

\section{E. Other Comprehensive Income}

Components of other comprehensive income (OCI) are components that are not recognized in the income statement but affect the increase or decrease in the value of equity [20]. OCI contains the value of gains or losses from fair value measurements. Other comprehensive income contains income and expense items (including reclassification adjustments) that are not recognized in profit or loss as required or permitted by financial accounting standards in Indonesia [10]. The existence of the Other Comprehensive Income section makes the information more comprehensive so that investors can see how the company's performance for making investment decisions then these decisions will affect stock returns.

Based on research conducted by Jahmani et al, other comprehensive income and its components are concluded to have value relevance [21]. According to Lin et al, other comprehensive income is tied to stock returns [22]. Research conducted by Ariyadi et al, shows the results that other comprehensive income (OCI) has an influence on stock returns [17]. In Groen's research, it was stated that other comprehensive income affects stock returns, which indicates that other comprehensive income has value relevance because shareholders respond to the value of other comprehensive income [3]. Then derived hypothesis, as follows:

\section{$\mathrm{H}_{3}$ : Other Comprehensive Income affects stock return.}

\section{F. Other Comprehensive Income with Low Subjectivity (SEC)}

In Lee and Park's research, the components of other comprehensive income are divided into 2 groups based on the level of subjective assessment, namely components with high subjectivity and components with low subjectivity [23]. Other comprehensive income components with low subjectivity are gains or losses on available-for-sale financial assets. This is because the measurement uses an active market quote price. Values with low subjectivity are more reliable and ultimately stimulate investors' responses in investing to affect stock returns. 
According to Jahmani et al the loss component of availablefor-sale financial assets has a value relevance [21]. Based on research conducted by Kahareningtyas shows the results that the component of profit (loss) of financial assets available for sale which is included in the category of Other Comprehensive Income with low subjectivity has an influence on stock returns [6]. From the explanation above, the following hypotheses are derived:

$\mathrm{H}_{4}$ : Other Comprehensive Income with Low Subjectivity affects stock return.

\section{G. Other Comprehensive Income with High Subjectivity} (N_SEC)

According to research conducted by Lee and Park, other comprehensive income components with high subjectivity consist of [23]:

- component of translation of foreign currency reports into reporting currencies,

- component of revaluation of fixed assets to their fair values,

- component of a defined benefit plan that is related to changes in actuarial assumptions,

- component of cash flow hedging activities, and

- component of association activities (associated entities and joint ventures).

In contrast to the OCI component with low subjectivity that relies on the fair value of active market quotes, this component relies on assumptions, judgments, and estimates in its measurement so that the information contains high subjectivity. Therefore, investors as external parties who are not involved in the assessment can see how the company uses estimates, assumptions, and judgment in making a measurement. Disclosure of the use of estimates, assumptions, and judgments in valuations will stimulate the response of users of this information through investment decisions that affect stock returns. Based on the results of research conducted by Ariyadi et al other comprehensive income with high subjectivity affects stock returns [17]. Information that contains subjectivity causes a high risk of information that is responded by investors. Then, the hypothesis is based on the explanation, as follows:

$\mathrm{H}_{5}$ : Other Comprehensive Income with High Subjectivity affects stock return.

\section{RESEARCH METHODOLOGY}

This research was conducted at Infrastructure, Utilities, and Transportation sector companies listed on the Indonesia Stock Exchange in 2014-2018. The objects of this research are net income (X1), comprehensive income (X2), other comprehensive income (X3), other comprehensive income with low subjectivity (X4), and other comprehensive income with high subjectivity (X5) as independent variables and stock returns (Y) as the dependent variable. The selection of research samples uses purposive sampling by establishing criteria for obtaining samples. The criteria for purposive sampling and the companies selected to be sampled are as in table 1 .

\section{TABLE I. CRITERIA FOR PURPOSIVE SAMPLING}

\begin{tabular}{|l|l|}
\hline \multicolumn{1}{|c|}{ Sample Criteria } & $\begin{array}{l}\text { Number of } \\
\text { Companies }\end{array}$ \\
\hline $\begin{array}{l}\text { Infrastructure, utility and transportation } \\
\text { companies are listed on the Indonesia Stock } \\
\text { Exchange }\end{array}$ & 74 \\
\hline $\begin{array}{l}\text { Infrastructure, utilities, and transportation } \\
\text { companies that are not included in companies } \\
\text { listed on the Indonesia Stock Exchange during the } \\
\text { study period and transportation }\end{array}$ & $(19)$ \\
\hline $\begin{array}{l}\text { Infrastructure, utilities, and } \\
\text { companies that do not present financial statements } \\
\text { in Indonesian Rupiah }\end{array}$ & \\
\hline $\begin{array}{l}\text { Infrastructure, utilities, and transportation } \\
\text { companies that do not have available data for this } \\
\text { research }\end{array}$ & $(20)$ \\
\hline $\begin{array}{l}\text { The number of companies that become research } \\
\text { samples }\end{array}$ & $\mathbf{1 0}$ \\
\hline
\end{tabular}

In this research, panel data regression analysis using Eviews software consists of 3 models to be selected, namely the common effect model, fixed effect model, random effect model. To estimate the regression model that will be chosen, 3 tests were performed to select the most appropriate model to use. The first is the chow (likelihood ratio) test to determine the chosen common effect model or fixed effect model. Second, the thirst test to determine the fixed effect model or random effect model chosen. And third, lagrange multiplier (LM) test to determine the common effect model or random effect model chosen. Then, the researchers conducted hypothesis testing. First, a partial test ( $t$ test) to see the effect of the independent variable partially on the dependent variable and secondly, the coefficient of determination (R2) to find out how much the variation of the independent variables can explain the dependent variable [19].

\section{RESULTS AND DISCUSSION}

Panel data regression analysis includes the variables net income (NIPS), comprehensive income (CIPS), other comprehensive income (OCI), other comprehensive income with low subjectivity (SEC), and other comprehensive income with high subjectivity (N_SEC). Panel data regression analysis is done using Eviews 9 where there are 3 models that will be selected as the most appropriate model to use. The 3 models are the common effect model, the fixed effect model, and the random effect model. We conducted tests to select the most appropriate model. Tests performed are chow test, Hausman test, and LM test. A chow test is performed to choose between the common effect model or the fixed effect model that is most appropriate for use. The basis for decision making is to look at the probability value of cross-section $F$. If the probability value of cross-section $F>0.05$ then we choose the common effect model.

\section{TABLE II. CHOW TEST}

\begin{tabular}{|c|c|}
\hline & Prob. \\
\hline Cross-section F & 0.1182 \\
\hline & Source: data processing with Eviews 9
\end{tabular}


In Table 2, it is shown that the results of the chow test show the probability value of cross-section $F$ is 0.1182 or greater than $\alpha(0.05)$, then the model chosen is the common effect model. Because the model chosen after the chow test is the common effect model then the hausman test is not performed and immediately proceed to the LM test to choose between the common effect model or the random effect model. The basis for decision making is to look at the probability value of the Breusch-Pagan. If the probability value of the Breusch-Pagan $>0.05$, then the common effect model is chosen.

TABLE III. LAGRANGE MULTIPLIER (LM) TEST

\begin{tabular}{|l|l|}
\hline & Cross-section \\
\hline Breusch-Pagan & $(0.3833)$ \\
\hline
\end{tabular}

In Table 3 it is shown that the LM test results show the probability value of the Breusch-Pagan cross-section is 0.3833 or greater than $\alpha(0.05)$, then the model chosen is the common effect model. In panel data regression, it is possible to have multicollinearity, autocorrelation, and heteroscedasticity problems. Therefore, a classical assumption test is performed to detect the problem and handle it. According to Gani and Amalia, multicollinearity testing can use the value of Variance Inflation Factor (VIF). If the VIF value is more than 10 then multicollinearity occurs [24].

TABLE IV. MULTICOLLINEARITY TEST

\begin{tabular}{|l|l|}
\hline \multicolumn{1}{|c|}{ Variables } & Cantered VIF \\
\hline NI & 1.519235 \\
\hline CI & 1.689170 \\
\hline OCI & 1.235656 \\
\hline SEC & 1.134194 \\
\hline N_SEC & 1.065391 \\
\hline
\end{tabular}

In Table 4, it can be seen that all independent variables (NIPS, CIPS, OCI, SEC, and N_SEC) do not have a VIF (centred VIF) value of more than 10 so that there is no multicollinearity. According to Nachrowi and Usman (2006) to detect and deal with the problem of heteroscedasticity, in Eviews 9 there is handling of problems with the white test. Then the autocorrelation test is done by looking at the upper and lower limits in the Durbin-Watson table. In the common effect model with the White (White's General Heteroscedasticity) test, the DW value is 1.969509 . In the DW table, the bottom value ( $\mathrm{dl})$ is 1.33457 , the top value $(\mathrm{du})$ is 1.77077, and the 4-du value is 2.22223. In the Durbin-Watson test rules, this model fulfils the requirements for being free from autocorrelation with the terms du $<$ DW $<4-$ du or $1.77077<1.969509<2.22223$. After handling multicollinearity, autocorrelation, and heteroscedasticity problems, the common effect model is as follows.
TABLE V. COMmon EFFECT Model (AFter Classical ASSUMPTION TEST)

\begin{tabular}{|l|l|l|l|}
\hline Variable & Coefficient & t-statistic & Prob. \\
\hline NIPS & 0.216299 & 3,112242 & 0,0033 \\
\hline CIPS & $-0,164921$ & $-2,857933$ & 0,0065 \\
\hline OCI & $-0,131916$ & $-2,915241$ & 0,0056 \\
\hline SEC & $-0,035861$ & $-1,186465$ & 0,2418 \\
\hline N_SEC & $-1,69 E+14$ & $-14,25640$ & 0,0000 \\
\hline Adj. R Squared = 0,092737 Prob(F-Statistic) \\
=0,097097
\end{tabular}

Source: data processing with Eviews 9

In Table 5, it can be seen the t-statistic value of independent variables. We compare the t-statistic value with ttable value to determine the effect from independent variables to dependent variable. The $t$-table value is 2,01537. The value of t-statistic from net income (NIPS) is 3,112242 greater than ttable value and positive. Net income affects stock returns positively and it means investors respond to net income information positively. This research has the same result as Darsono's research which show that net income has value relevance [16]. This research also has the same result as Aryati and Wibowo's research which show that net income affects stock returns [7]. Net income contains information about the company's performance. The information of net income provides a signal for financial reports users. Investors can use the information for the investment decision making. When there is an increase in net income, investors will respond this information positively so it will increase stock returns, and vice versa. The t-statistic value of comprehensive income (CIPS) is $-2,857933$ greater than ttable value and negative. Comprehensive income affects stock returns negatively and it means investors respond to comprehensive income information negatively. This research has the same result as Rejeki and Warastuti's research which show that comprehensive income affects stock returns [4]. Comprehensive income provides more information and makes reports more relevant. Investors use the comprehensive income information for the investment decision making. When there is an increase in comprehensive income, investors will respond it negatively because comprehensive income also contains OCI components that has subjectivity so, it will decrease stock returns, and vice versa. The t-statistic value of other comprehensive income (OCI) is 2,915241 greater than t-table value and negative. Other comprehensive income affects stock returns negatively and it means investors respond to OCI information negatively. This research has the same result as Groen's research which show that OCI affects stock returns [3]. OCI has components that are not in net income. OCI can provide additional information that useful for investors to make investment decisions. When there is an increase in OCI, investor will respond it negatively because the components contain subjectivity so, it will decrease stock returns, and vice versa. The t-statistic value of other comprehensive income with high subjectivity (N_SEC) is $-14,25640$ greater than t-table value and negative. Other comprehensive income with high subjectivity affects stock returns negatively. This research has the same result as the research conducted by Ariyadi et al which show that other comprehensive income with high subjectivity affects stock returns [17]. Other comprehensive income with high subjectivity are useful for investment decision making. This component contains high subjectivity 
because of the judgments and assumptions to measure the value so, investors respond this information negatively. The increase in other comprehensive income with high subjectivity affects the decrease in stock returns, and vice versa. The tstatistic value of other comprehensive income with low subjectivity (SEC) is $-1,186465$ less than t-table value. Other comprehensive income with low subjectivity does not affect stock returns so, the increase in other comprehensive income with low subjectivity does not affect the decrease in stock returns, and vice versa. This result shows that the information of other comprehensive income with low subjectivity is not used by investors as a basis for investment decision making because the infrastructure, utilities, and transportation companies do not have much value in available financial assets for sale.

\section{CONCLUSION}

This research was conducted on infrastructure, utility and transportation sector companies listed on the Indonesia Stock Exchange in the 2014-2018 period with panel data regression analysis using Eviews 9. The results of this study indicate that:

- Net income has value relevance. Net income affects stock returns positively. Investors rely on net income information and this information is responded positively so that the increase in net income affects the increase in stock returns, and vice versa.

- Comprehensive income, other comprehensive income, and other comprehensive income with high subjectivity (N_SEC) have value relevance. This variable affects stock returns. However, because the value contains subjectivity due to assumptions and judgments in the measurement, the information is responded negatively by investors so, the variable affects stock returns negatively. The increase in comprehensive income, other comprehensive income, and other comprehensive income with high subjectivity (N_SEC) affects the decrease in stock returns, and vice versa.

Other comprehensive income with low subjectivity (SEC) included in the component of financial assets available for sale has no value relevance. This is because the infrastructure, utilities, and transportation companies do not have much value in available financial assets for sale.

This information is not used as a basis for investors to make investment decisions so it does not affect stock returns. When an increase in the value of other comprehensive income with low subjectivity (SEC) does not affect the decline in stock returns, and vice versa.

\section{REFERENCES}

[1] W.D. Adhawati and S. Aisyah, Pengaruh Other Comprehensive Income, Subjektifitas dari Other Comprehensive Income dan Nilai Pasar terhadap Harga Saham (Pada Perusahaan Properti, Real Estate dan Konstruksi Bangunan yang Terdaftar di Bursa Efek Indonesia Tahun 2013-2017). Universitas Pasundan, 2019.

[2] D.M. Rissi, Pengaruh Kualitas Audit Terhadap Hubungan Pengungkapan Other Comprehensive Incomedengan Majemen Laba pada Perusahaan yang Terdaftar di Bursa Efek Indonesia. Universitas Andalas, 2016.

[3] A. Groen, The value relevance of other comprehensive income under IAS 1: an empirical investigation. Amsterdam Business School, 2010.

[4] T.S. Rejeki and Y. Warastuti, "Pengaruh Perubahan Laba Bersih, Perubahan Laba Komprehensif, dan Perubahan Peringkat Obligasi Terhadap Return Saham," Jurnal Akuntansi Bisnis, vol. XI, no. 21, 2012.

[5] A.T. Yudiman, D. Darmansyah, and N. Ahmar, "Relevansi Nilai Net Income, Comprehensive Income dan Other Comprehensive Income pada Perusahaan Manufaktur," Jurnal Ilmiah Professional Indonesia (JIPI), vol. 1 , no. 1,2017

[6] F. Kahareningtyas, Relevansi Nilai Other Comprehensive Income dan Komponen-Komponen Other Comprehensive Income untuk Tujuan Pembuatan Keputusan Investasi (Studi Kasus pada Perusahaan Terdaftar di BEI Periode 2011-2015). Universitas Muhammadiyah Yogyakarta, 2016.

[7] T. Aryati and N.N. Wibowo, "Relevansi Nilai Informasi Other Comprehensive Income dan Net Income," Jurnal Media Riset Akuntansi, Auditing \& Informasi, vol. 17, no. 1, 2017.

[8] J. Godfrey, A. Hodgson, A. Tarca, J. Hamilton, and S. Holmes, Accounting Theory 7th Edition. John Wiley and Sons Australia Ltd, 2010 .

[9] H.S. Sulistyanto, Manajemen Laba: Teori dan Model Empiris. Jakarta: Yrama Widya, 2008.

[10] Dewan Standar Akuntansi Keuangan. Pernyataan Standar Akuntansi Keuangan (PSAK). Jakarta: IAI, 2009

[11] J. Francis and K. Schipper, "Have Financial Statements Lost Their Relevance?" Journal of Accounting Research, vol. 37, no. 2, Autumn 1999.

[12] H. Hery, Cara Mudah Memahami Akuntansi: Inti Sari Konsep Dasar Akuntansi. Prenada Media Group, 2015

[13] H. Hery, Praktis Menyusun Laporan Keuangan: Cepat \& Mahir Menyajikan. Grasindo, 2015.

[14] C.S.A. Cheng, J.K. Cheung, and V. Gopalakrishnan, On The Usefulness of Operating Income, Net Income, and Comprehensive Income in Explaining Security Returns. Routledge, 2012.

[15] T. Obinata, Concept and Relevance of Income. University of Tokyo, 2002.

[16] D. Darsono, Dampak Konservatisma Terhadap Relevansi Nila Informasi Akuntansi di Indonesia. Universitas Gadjah Mada, Yogyakarta, 2012.

[17] F. Ariyadi, A. Wiratno, and D. Darmansyah, "Relevansi Nilai dan Subjektifitas dari Other Comprehensive Income pada Perusahaan Industri Jasa Keuangan,” Jurnal Ilmiah Professional Indonesia (JIPI), vol. $2,2018$.

[18] M. Brimble and A. Hodgson, The value relevance of comprehensive income and components for industrial firm. University of Amsterdam, 2005 .

[19] N.D. Nachrowi and H. Usman, Pendekatan Populer dan Praktis, 2006.

[20] K. Born, Did Base III miss the point? The role of IFRS's Other Comprehensive Income during the financial crisis. Anchor Academic Publishing, 2017.

[21] Y. Jahmani, H.Y. Choi, Y. Park, and G.J. Wu, "The Value Relevance of Other Comprehensive Income and Its Components," The Institute for Business and Finance Research, vol. 9, no. 1, 2017.

[22] S.W. Lin, O.J. Ramond, and J.-F. Casta, Value Relevance of Comprehensive Income and Its Components: Evidence from Major European Capital Markets, 2007.

[23] C. Lee and M.S. Park, "Subjectivity in fair-value estimates, audit quality, and informativeness of other comprehensive income," Advances in Accounting, incorporating Advances in International Accounting, vol. 29, no. 2, pp. 218-231, 2013.

[24] I. Gani and S. Amalia, Alat analisis data: Aplikasi Statistik untuk Penelitian Bidang Ekonomi dan Sosial. Andi Publisher, 2015. 